\title{
Sensory quality of meat from Santa Inês lambs fed with guava (Psidium guajava L.) agroindustrial by-product
}

\author{
Roberto Germano COSTA ${ }^{1 *}$ (D), Maria Caroline de Almeida CAVALCANTI ${ }^{1}$, Priscila Torres NOBRE ${ }^{1}$, \\ Rita de Cássia Ramos do Egito QUEIROGA¹, Geovergue Rodrigues de MEDEIROS ${ }^{2}$, Nelson Vieira da SILVA ${ }^{3}$, \\ Ana Sancha Malveira BATISTA ${ }^{4}$, José Teodórico de ARAÚJO FILHO ${ }^{5}$
}

\begin{abstract}
The aim of this work was to determine the sensory quality (flavour, odour, tenderness, juiciness and overall acceptability) and physicochemical characteristics of meat from Santa Inês lambs fed with diets containing guava agroindustrial by-product (GAB). Was used samples of the longissimus lumborum of 40 entire males with an average slaughter weight of $32.0 \mathrm{~kg}$, after approximately 105 days in a feedlot. Animals were randomly placed into four treatments ( 10 replicates per treatment) and fed with different levels of $\operatorname{GAB}(0,20,40$ and $60 \%)$. Among the attributes examined, only odour was not influenced by the GAB. Inclusion of $40 \% \mathrm{GAB}$ in diets (in place of corn) produced meat which satisfied consumer demands in terms of fresh colour, although with less intense flavour and tenderness. Although the factors juiciness and overall acceptability did not differ among the highest levels of $\mathrm{GAB}$, we recommend to use $\mathrm{GAB}$ addition of up to $40 \%$ to avoid compromising on animal performance and consumer sensory characteristics.
\end{abstract}

Keywords: flavour; juiciness; meat quality; odour; tenderness.

Practical Application: Guava by-product can be used in the diet without impairing the sensory quality of meat.

\section{Introduction}

In northeastern Brazil, inadequate nutrition is impeding the optimisation of sheep productivity. For of the domestic herd, forage is strongly affected by seasonal variations, with poor rainfall throughout the year. The using food concentrates in high proportions to supplement low quality forage have been conducted, but this practice may adversely affect production costs (Leão et al., 2011).

An alternative to diminish negative effects on animal performance is the use of residues derived from agroindustry (Henrique et al., 2013; Lima et al., 2014; Geron et al., 2015). Worldwide, millions of tons of waste from agro-industrial activities are generated. The Brazil is considered the third largest fruit producer (Food and Agriculture Organization of the United Nation, 2011), with around 353 thousand tons per year, waster China and India (Food and Agriculture Organization of the United Nation, 2011). Among the alternative foods available in Brazil, guava (Psidium guajava L., Myrtaceae family) stands out. Guava agroindustrial by-product (GAB), which is mainly discarded in landfills without any treatment causing damage to the environment, consists of peeling, pulping and mainly pulp processing seeds (Chang et al., 2014). Thus, the search for food alternatives, such as guava by-product (Psidium guajava L.), to minimise nutritional deficiency is crucial for the development of the sheep industry, which is an alternative during periods of food scarcity.

In previous experiments, ruminants have been fed with guava residue, which is composed largely of seeds. Lousada et al. (2005) showed a high consumption of the feed, but with limitations in its use for cattle, probably due to the high tannin and lignin contents in the fruit seeds. However, the inclusion of tannins in animal diets can influence the colour of the meat due to an indirect effect on oxidative stability, promoted by a possible modification of the lipid profile of the muscles (Luciano et al., 2009). This effect may be enhanced by guava seeds, which contain 77.35\% linoleic acid (Uchoa-Thomaz et al., 2014).

Among the principal attributes of palatability, flavour and colour play important roles, and the sensory properties for the product quality can be easily assessed (Liu et al., 1995). Thus, the development of rational farming techniques that produce higher yields and quality to meet increasing demands are critical. The use of human senses in the perception of the features that provide the highest customer satisfaction has become the definition of "quality", highlighting juiciness, colour, tenderness, flavour and odour as important sensory characteristics of lamb meat (Osório et al., 2009). The aim of this work was to determine the sensory quality (flavour, odour, tenderness, juiciness and overall 
acceptability) and physicochemical characteristics of meat from Santa Inês lambs fed with diets containing guava agroindustrial by-product (GAB).

\section{Materials and methods}

\subsection{Animals and management}

This study was approved by the Animal Ethics Committee of the Federal University of Paraiba (UFPB), Brazil (protocol no. $2305 / 14)$.

This study was conducted at the Federal Institute of Education, Science and Technology of Pernambuco (IFPE)-Campus of Belo Jardim. The city is located in the geographical area covered by the Brazilian semiarid region at coordinates $08^{\circ} 20^{\prime} 9^{\prime \prime} \mathrm{S}$ and $36^{\circ} 25^{\prime} 28^{\prime \prime} \mathrm{W}$. The weather is rainy tropical, with dry summers.

The study used 40 entire Santa Inês male lambs with an average age of 120 days and a weight of $17.41 \pm 1.27 \mathrm{~kg}$. The Santa Ines breed is found in large numbers in the Northeast region. This breed is rustic and well adapted to the Northeast region. The Santa Ines breed became an excellent alternative in the production of meat (Carneiro et al., 2007). At the beginning of the experiment, the animals were weighed and dewormed with a subcutaneous injection of $1 \%$ ivermectin. All lambs were housed in individual stalls $\left(1.8 \mathrm{~m}^{2}\right)$, with free access to feed and water to allow individual assessment of feed consumption. The adjustment period was 15 days, with weekly weighing from the beginning of the experiment until animals reached slaughter weight.

The animals were randomly assigned to four dietary treatments in a completely randomised design, with 10 replicates for each treatment. Corn was substituted for GAB in the range of 0, 20, 40 and $60 \%$ in diets containing Tifton 85 (Cynodon dactylon L.), soybean meal, vegetable oil and urea (Table 1); the composition of the ingredients is shown in Table 2. Feed samples were collected from each experimental period for chemical analysis o dry matter (DM; AOAC method 934.01), crude protein (CP; Kjeldahl method, AOAC method 984.13), ether extract (EE; AOAC method 920.39), neutral detergent fiber (NDF; method of Holst, 1973), and acid detergent fiber (ADF; AOAC method 973.18) (Association of Official Analytical Chemists, 2005).

Diets were formulated to a gain of $250 \mathrm{~g} /$ day in forage, with a concentrate ratio of 30:70, as recommended by the National Research Council (2007). Experimental diets were offered ad libitum twice daily at 07:30 am and 04:30 pm as a complete mixture. The food offered and the leftovers were weighed to calculate the voluntary intake and adjusted daily, maintaining leftovers at $10 \%$ due to the consumption of the previous day. The animals were slaughtered at $32.0 \mathrm{~kg}$ (live weight) after approximately 105 days in a feedlot.

\subsection{Physicochemical analysis}

A Minolta colour meter (model CR 200b, Minolta Camera Meter, Japan) was used to measure meat colour coordinates $\mathrm{L}^{*}$ (lightness), $\mathrm{a}^{\star}$ (redness) and $\mathrm{b}^{\star}$ (yellowness) in the muscle longissimus lumborum. Triplicate readings were performed on non-overlapping zones of the samples and average values were calculated. The measurement of meat $\mathrm{pH}$ was performed $24 \mathrm{~h}$ post mortem (Association of Official Analytical Chemists, 2005), by using a digital potentiometer (DIGIMED, model pH 300M, São Paulo/Brazil), equipped with a glass electrode.

Table 1. Composition and percentage chemical of the experimental diets according to levels of Guava (Psidium guajava L.) agroindustrial by-product $(\mathrm{GAB})$ in substitution to corn in the diet.

\begin{tabular}{|c|c|c|c|c|}
\hline & \multicolumn{4}{|c|}{ Substitution Levels (\%) } \\
\hline & 0 & 20 & 40 & 60 \\
\hline \multicolumn{5}{|l|}{ Ingredient (\%DM) } \\
\hline GAB & 0.0 & 8.2 & 16.4 & 24.6 \\
\hline Hay tifton & 30.0 & 30.0 & 30.0 & 30.0 \\
\hline Grain ground corn & 41.0 & 32.8 & 24.6 & 16.4 \\
\hline Soybean meal & 22.0 & 22.0 & 22.0 & 22.0 \\
\hline Vegetable oil & 5.0 & 5.0 & 5.0 & 5.0 \\
\hline \multicolumn{5}{|c|}{ Chemical composition based DM (\%) } \\
\hline Dry matter, DM & 84.39 & 84.62 & 84.85 & 85.09 \\
\hline Crude protein, CP & 17.67 & 17.74 & 17.81 & 17.88 \\
\hline Ether extract, EE & 8.29 & 8.69 & 9.10 & 9.42 \\
\hline Non-fiber carbohydrates, NFC & 28.86 & 24.73 & 20.55 & 16.49 \\
\hline Lignin & 2.47 & 3.99 & 5.50 & 7.02 \\
\hline Total tannin, TT & 0.00 & 0.50 & 2.40 & 4.80 \\
\hline Total digestible nutrients, TDN & 79.18 & 75.04 & 70.89 & 66.74 \\
\hline Metabolizable energy, ME & 2.86 & 2.70 & 2.55 & 2.41 \\
\hline
\end{tabular}


Costa et al.

Table 2. Chemical composition of ingredients used in the experimental diets.

\begin{tabular}{lcccccccc}
\hline \multicolumn{1}{c}{ Ingredient } & DM & OM & CP & EE & NDF $^{1}$ & ADF $^{1}$ & TDN $^{1}$ & Lignina $^{1}$ \\
\hline $\mathrm{GAB}^{2}$ & 90.35 & 97.47 & 9.44 & 10.72 & 75.30 & 58.18 & 34.57 & 19.70 \\
Hay tifton & 80.73 & 92.61 & 7.98 & 1.74 & 78.64 & 39.04 & 55.74 & 5.50 \\
Grain ground corn & 87.51 & 96.99 & 8.56 & 5.71 & 13.52 & 3.83 & 85.94 \\
Soybean meal & 87.79 & 93.77 & 47.07 & 2.02 & 15.54 & 9.60 & 80.68 & 1.19 \\
${ }^{1}$ Vegetable oil & 100.00 & - & - & 99.90 & - & - & 1.52 \\
${ }^{1}$ Urea & 100.00 & - & 281.00 & - & - & - & - \\
\hline
\end{tabular}

${ }^{1}$ Values of the composition table of Valadares et al. (2006); ${ }^{2}$ Guava (Psidium guajava L.) agroindustrial by-product (GAB).

Table 3. Descriptors used in the quantitative descriptive sensory analysis of lamb meat.

\begin{tabular}{ll}
\hline \multicolumn{1}{c}{ Descriptor } & \multicolumn{1}{c}{ Definition } \\
\hline Lamb flavour $^{\mathrm{a}}$ & $\begin{array}{l}\text { Mixed experience of olfactory, gustatory and tactile sensations perceived during the tasting. Flavour intensy of cooked } \\
\text { lamb } \\
\text { Lamb odour }\end{array}$ \\
& $\begin{array}{l}\text { Organoleptic property perceived by olfactory organ when certain volatile substances are the smell. Odour intensity of } \\
\text { cooked lamb }\end{array}$ \\
Tenderness $^{\mathrm{b}}$ & $\begin{array}{l}\text { Force required to compress a piece of meat between the molar teeth, evaluated at first bite } \\
\text { Juiciness }^{\mathrm{c}}\end{array}$ \\
Overall acceptability $^{\mathrm{d}}$ & $\begin{array}{l}\text { Perception of the amount of liquid released from the meat sample in the mouth after } 5^{\text {th }} \text { bite } \\
\text { Sum of quality attributes that will contribute to determining the degree of product acceptance by panellists }\end{array}$
\end{tabular}

${ }^{\mathrm{a}} 0=$ Not detected, $9=$ very intense; ${ }^{\mathrm{b}} 0=$ very tough, $9=$ very tender; ${ }^{\mathrm{c}} 0=$ very dry, $9=$ very juicy; ${ }^{\mathrm{d}} 0=$ very bad, $9=$ very good.

To analyse the chemical composition of the longissimus muscle, samples from each animal were thawed in a conventional refrigerator for 24 hours after removal of the connective tissue, held by trituration in a domestic blender to obtain a homogeneous mass. We evaluated moisture content, ash, crude protein (CP), and ethereal extract (EE) according to the Association of Official Analytical Chemists (2005).

\subsection{Muscle sampling and sensory analysis}

The panel test was performed at the Laboratory of Food Analysis, Department of Nutrition, Center for Health Sciences, Federal University of Paraíba, Brazil. The day before each session, longissimus lumborum muscle samples of Santa Inês lambs of about $200 \mathrm{~g}$ were thawed inside an over-wrap plastic film for $24 \mathrm{~h}$ in a chiller $\left(0-4^{\circ} \mathrm{C}\right)$. After thawing, samples were cut into cubes of approximately $2 \mathrm{~cm}$ (free of visible connective tissue), baked in an electric oven at $170{ }^{\circ} \mathrm{C}$ until the temperature, monitored by a digital thermometer (Delta OHM model HD 9218), reached $70{ }^{\circ} \mathrm{C}$ at the geometric centre of the meat (after about $8 \mathrm{~min}$ ). There was no addition of salt or flavourings. After cooking, the samples were wrapped in aluminium foil and transferred to beakers coded with 3-digit random numbers in a water bath and maintained at $55^{\circ} \mathrm{C}$ until analyses; they were then randomly distributed to the panellists. Sensory analysis was performed in individual cabins with controlled environmental conditions and a red light to obscure meat colour (International Organization for Standardization, 1988). To cleanse their palates between samples, panellists were given bottled water and breadsticks. Analysis was performed by a team of 10 selected and trained panellists (International Organization for Standardization, 1993), 6 males and 4 females aged 20-30 years. The panellists had been selected among undergraduate students of the Department of Nutrition and graduate students of the Department of Food Chemistry and Technology at UFPB. The test used a quantitative descriptive method within an incomplete design that included 10 plates containing four samples, each divided in three sessions. Thus, the sensory analysis included the meat of every animals of the four treatments (10 in each treatment). The analysis was based on five sensory descriptors (Table 3 ); each descriptor was evaluated using a 9-point hedonic scale semi-structured and continuous anchored at extremities with terms that express intensity.

\subsection{Statistical analysis}

The data of performance characteristics and physicochemical were subjected to analysis of variance (ANOVA) and regression analysis. The data of sensory were compared using the Ryan-Einot-Gabriel-Welscha test $(\mathrm{P}<0.05)$. For the panel test, the mathematical model was as follows: $\mathrm{Y}_{\mathrm{ijk}}=\mu+\mathrm{T}_{\mathrm{i}}+\mathrm{P}_{\mathrm{j}}+\mathrm{S}_{\mathrm{k}}+\mathrm{e}_{\mathrm{ijk}}$, where $Y_{i j k}$ is the dependent variable, $\mu$ is the population average, $\mathrm{T}_{\mathrm{i}}$ is the fixed effect of the treatment $\mathrm{i}$, varying from 1 to $4, \mathrm{P}_{\mathrm{j}}$ is the fixed effect of the panellist, $S_{k}$ is the fixed effect of the session and $\mathrm{e}_{\mathrm{ijk}}$ is the error. In the statistical analysis of the sensory data, the effect 'panellist' had a significant $(P<0.01)$ effect on all parameters, which is common in sensory analysis because of the different ways in which the scale is used (Rousset-Akrim et al., 1997). Then, were performed canonical analyses using the procedure CANDISC. This procedure was used to obtain the total standard canonical coefficients and the total variation explained by each canonical variable. All analyses were performed using the Statistical Analysis System (2001) software.

\section{Results and discussion}

The amount of GAB in the diet influenced final weight gain and average daily weight characteristics $(P<0.05)$. Final lamb weight showed an inverse relationship with the levels of GAB $(P<0.05)$, suggesting that with increasing GAB percentage (in place of corn) in the diet, the animals showed a mean weight reduction of $16 \mathrm{~g}$ (Table 4 ). 
Table 4. Growth performance and physicochemical composition of the Longissimus lumborum muscle of Santa Ines lambs fed with increasing levels of Guava (Psidium guajava L.) agroindustrial by-product.

\begin{tabular}{|c|c|c|c|c|c|c|c|}
\hline \multirow{2}{*}{ Variables } & \multicolumn{4}{|c|}{ Substitution levels (\%) } & \multirow{2}{*}{ SE } & \multicolumn{2}{|c|}{$P$ - value ${ }^{1}$} \\
\hline & 0 & 20 & 40 & 60 & & Linear & Quadratic \\
\hline Initial weight. $\mathrm{kg}$ & 17.45 & 17.34 & 17.11 & 16.89 & 0.03 & 0.393 & 0.908 \\
\hline${ }^{1}$ Final weight. kg & 32.47 & 32.13 & 31.94 & 25.30 & 0.21 & $<0.001$ & 0.160 \\
\hline${ }^{2}$ Daily weight gain. kg & 0.26 & 0.22 & 0.22 & 0.12 & 0.01 & $<0.001$ & 0.061 \\
\hline DMI, kg/day & 1.35 & 1.29 & 1.25 & 1.18 & 0.28 & 0.189 & 0.408 \\
\hline Protein & 24.81 & 24.86 & 25.00 & 24.32 & 0.13 & 0.259 & 0.178 \\
\hline Lipids & 2.57 & 2.61 & 2.48 & 2.80 & 0.06 & 0.374 & 0.309 \\
\hline${ }^{3}$ Moisture & 75.61 & 75.66 & 75.80 & 77.08 & 0.17 & $<0.001$ & 0.144 \\
\hline Ash & 1.12 & 1.10 & 1.09 & 1.11 & 0.01 & 0.672 & 0.120 \\
\hline $\mathrm{pH}(24 \mathrm{~h})$ & 5.55 & 5.75 & 5.82 & 5.89 & 0.05 & 0.076 & 0.595 \\
\hline Instrumental colour: $\mathrm{L}^{*}$ & 25.50 & 31.18 & 30.09 & 29.83 & 1.33 & 0.328 & 0.275 \\
\hline$a^{*}$ & 9.51 & 31.18 & 30.09 & 29.83 & 0.53 & 0.834 & 0.530 \\
\hline $\mathrm{b}^{*}$ & 4.70 & 3.83 & 4.95 & 5.56 & 0.43 & 0.352 & 0.405 \\
\hline
\end{tabular}

Daily weight gain of the animals decreased when GAB was added to the diet. The weight gain values ranged from $120 \mathrm{~g} /$ day with $60 \% \mathrm{GAB}$ to $260 \mathrm{~g} /$ day without GAB. The higher the degree of substitution, the lower the daily weight gain. This weight reduction was probably due to a decrease in the concentration of energy and increases in the fibrous constituents neutral detergent fibre (NDF) and acid detergent fibre (FDA), resulting in reduced intake of dry matter (DMI). With 20 and $40 \%$ of GAB, the daily weight gain was close to $250 \mathrm{~g} /$ day, which is recommended by the National Research Council (2007).

Values for proteins, lipids and ash were 42.74, 2.61 and 1.10\%, respectively, with no significant differences $(P>0.05)$ between treatments (Table 4 ). The moisture content was influenced by substitution levels, showing a linear increase $(P<0.05)$ and an increase of $22.8 \mathrm{mg} / 100 \mathrm{~g}$ for each $\mathrm{GAB}$ unit increase in the diet, which may be related to live weight at slaughter, which was higher in treatments with 0,20 and $40 \%$. This indicates that the increase in live weight at slaughter reduces the moisture content (Table 4). Moisture content is an important factor in meat composition, as it influences the yield and final product quality, contributing to juiciness and palatability (Santana et al., 2016). The overall chemical composition of the samples of this study is consistent with that reported by Leão et al. (2011).

We observed no significant differences $(P>0.05)$ in terms of colour intensity of the fresh meat between treatments; using a colour change scale ranging from pink to red. Brightness values $\left(L^{*}\right)$ ranged from 25.50 to 30.09 . However, Hopkins (1996) suggests that when the average value of $\mathrm{L}^{*}$ is greater than or equal to 34 , the consumers regard the meat colour as acceptable. Lamb diets with or without the addition of GAB resulted in a red to brown meat colour. Thus, it is likely that the condensed tannin levels in the diet were not sufficient to have an effect on the oxidative stability of the meat colour promoted by a possible change of the lipid profile of the muscles due to lipid metabolism in ruminants, which involves biohydrogenation (Luciano et al., 2009). A literature review of Vasta \& Luciano (2011) found that the use of polyphenols positively influenced the oxidative stability of meat. However, Min \& Hart (2003) state that concentrations above $55 \mathrm{~g} \mathrm{CT} / \mathrm{kg}$ DM generally reduce voluntary consumption and digestibility of the feed in ruminants. In terms of the parameters $\mathrm{a}^{*}$ and $\mathrm{b}^{*}$, there was no difference between treatments $(P>0.05)$, although Khliji et al. (2010) state that the value of $a^{*}$ is most strongly related to consumer perception of fresh meat; values equal to or greater than 9.5 represent an acceptable meat colour. Thus, by analyzing color as a consumer acceptability variable, the $40 \%$ level was more accepted than the GAB level of $60 \%$.

With the sensory analysis, we observed differences $(P<0.05)$ for the variables flavour, tenderness, juiciness and overall acceptability (Table 5). Treatments with higher levels of GAB resulted in less intense flavour, ranging from 5.27-3.68.

Several studies show that the taste of sheep meat is influenced by the animal's diet; meat from animals fed with concentrate shows higher flavour intensity than that of grazing sheep (Priolo et al., 2002; Borton et al., 2005; Resconi et al., 2009). We found similar results in this study. With GAB addition, the animals received less total digestible nutrients (TDN) and more NDF. Furthermore, "lamb flavour" is a general description that originates from various compounds that can interact and can therefore be subjective (Resconi et al., 2009).

There was no influence of GAB levels on odour, which showed moderate (average of 4.1) levels. This result is consistent with the measured meat fat, which was not influenced by levels of GAB. Costa et al. (2008) observed that sheep meat goat odour is related to the fat content present in the muscle; the greater the fat content, the more intense the mead odour.

The GAB level of $40 \%$ presented tender meat (5.08). Santana et al. (2016) claim that the tenderness, flavour and overall acceptability of the meat are directly related to the fat content and moisture of the meat, which will raise awareness of the organoleptic characteristics of the meat consumer. The highest average for descriptors to of juiciness was the level of $40 \%$, but it showed no significant difference to the level of $60 \%$ of GAB replacement. Resconi et al. (2009) states that the parameters juiciness and tenderness are positively correlated. 
Table 5. Mean values of attributes of the sensory analysis of meat samples from Santa Inês sheep fed with diets containing increasing levels of Guava (Psidium guajava L.) agroindustrial by-product.

\begin{tabular}{|c|c|c|c|c|c|}
\hline \multirow{2}{*}{ Attributes } & \multicolumn{4}{|c|}{ Substitution levels (\%) } & \multirow{2}{*}{ SE } \\
\hline & 0 & 20 & 40 & 60 & \\
\hline Lamb flavour & $5.27 \mathrm{a}$ & $4.65 \mathrm{ab}$ & $3.68 c$ & $4.07 \mathrm{bc}$ & 0.23 \\
\hline Lamb odour & 4.31 & 4.19 & 3.94 & 3.95 & 0.25 \\
\hline Tenderness & $4.71 \mathrm{ab}$ & $3.50 \mathrm{c}$ & $5.08 \mathrm{a}$ & $4.21 \mathrm{~b}$ & 0.20 \\
\hline Juiciness & $3.37 \mathrm{a}$ & $2.68 b$ & $3.42 \mathrm{a}$ & $3.18 \mathrm{ab}$ & 0.19 \\
\hline Overall acceptability & $4.36 \mathrm{ab}$ & $4.13 \mathrm{~b}$ & $4.81 \mathrm{a}$ & $4.58 \mathrm{ab}$ & 0.17 \\
\hline
\end{tabular}

Means followed by different letters in the lines differ by test Ryan-Einot-Gabriel-Welsch $(P<0.05)$. SE $=$ standard error.

Table 6. Total canonical (CAN) structure based on sensory attributes evaluated in the meat from lambs fed with different levels of Guava (Psidium guajava L.) agroindustrial by-product.

\begin{tabular}{lrrr}
\hline \multicolumn{1}{c}{ Attributes } & CAN1 & CAN2 & CAN3 \\
\hline Lamb flavour & 0.30122 & -0.73983 & -0.22092 \\
Lamb odour & -0.11437 & -0.32652 & 0.09803 \\
Tenderness & 0.26927 & $\mathbf{0 . 9 3 2 9 6}$ & -0.87484 \\
Juiciness & 0.02573 & -0.14440 & 1.15045 \\
Overall acceptability & $\mathbf{- 0 . 3 6 9 2 6}$ & -0.62012 & -0.17514 \\
Eigenvalues & 0.08912 & 0.04877 & 0.00768 \\
Cum. Prop. & 0.61222 & 0.94723 & 1.00000 \\
\hline
\end{tabular}

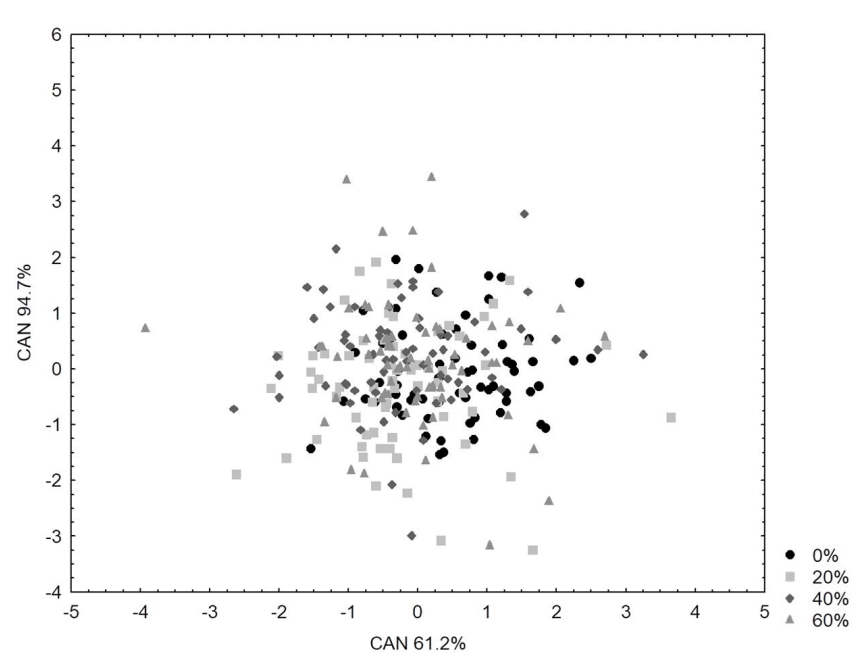

Figure 1. Canonical representation of the sensory attributes of meat from Santa Inês sheep fed with increasing levels of Guava (Psidium guajava L.) agroindustrial by-product (GAB).

For overall acceptability, the sum of descriptors contributing to the acceptance of the lamb meat ranged from 4.13 to 4.81 , indicating that the meat has moderate acceptance. The GAB levels of 40 and $60 \%$ had the same acceptance among the panellists. However, the level of $60 \%$ GAB would not be viable since it adversely affects animal performance.

Overall, the results of sensory parameters were homogeneous probably due to the uniformity of the fat content (Table 4), which is associated with the relevant consumer sensory characteristics for tenderness, flavour and juiciness. In the present study, canonical analysis, based on sensory attributes, allowed identification of canonical variables (CAN1 and CAN2), which added $61 \%$ and $94 \%$ of total variation, respectively (Table 6), indicating large reduction in sample space, with little loss to explain the total variation (6\%). Some studies with sensorial attributes suggest canonical analysis can reduce sample space with loss very close to this value (Nguyen \& Wang, 2012; Galán-Soldevilla et al., 2013). The attributes sensorial showed the greatest contribution in the two canonical variables, which were (in increasing order of importance) tenderness, lamb flavour and overall acceptability.

As shown in Figure 1, there is no group formation, but only one group. It is observed that the treatments are very homogeneous. In MANOVA the value of $\mathrm{P}$ did not present significant difference $(P>0.05)$ for the attributes studied

\section{Conclusions}

The addition of $40 \%$ of $\mathrm{GAB}$ do the diet of lambs resulted in satisfying meat colour, but less intense flavour and tenderness. Although juiciness and overall acceptability did not differ among the highest levels of $\mathrm{GAB}$, an addition of up to $40 \%$ is recommended to avoid compromising on animal performance and consumer sensory characteristics.

Santa Inês ewes fed diets containing guava by-products at levels of up to $40 \%$ corn substituted by guava by-product showed e can be used as a viable alternative for the production of sheep meat without compromising to animal performance and sensory characteristics of the consumer

\section{Acknowledgements}

The authors would like to thank CAPES (Coordination for Improvement of Higher Level Personnel) for financing the project and the Federal University of Paraíba - Brazil (UFPB). 


\section{References}

Association of Official Analytical Chemists - AOAC. (2005). Official methods of analysis of the AOAC International (18th ed.). Gaithersburg: AOAC.

Borton, R. J., Loerch, S. C., McClure, K. E., \& Wulf, D. M. (2005). Comparison of characteristics of lambs fed concentrate or grazed on ryegrass to traditional or heavy slaughter weights I. Production, carcass, and organoleptic characteristics. Journal of Animal Science, 83(3), 679-685. http://dx.doi.org/10.2527/2005.833679x. PMid:15705765.

Carneiro, P. L. S., Malhado, C. H. M., Souza, A. A. O. Jr., Silva, A. G. S., Santos, F. N., Santos, P. F., \& Paiva, S. R. (2007). Growth rate and phenotypic diversity among crosses of Dorper ovines and local breeds. Pesquisa Agropecuária Brasileira, 42(7), 991-998. http:// dx.doi.org/10.1590/S0100-204X2007000700011.

Chang, Y. P., Tan, M. T., Lok, W. L., Pakianathan, S., \& Supramaniam, Y. (2014). Making use of guava seed (Psidium guajava L): the effects of pre-treatments on its chemical composition. Plant Foods for Human Nutrition, 69(1), 43-49. http://dx.doi.org/10.1007/s11130013-0396-3. PMid:24292972.

Costa, R. G., Cartaxo, F. Q., Santos, N. M., \& Queiroga, R. C. R. E. (2008). Goat and sheep meat: fatty acids composition and sensorial characteristics. Revista Brasileira de Saúde e Produção Animal, 9(3), 97-506.

Food and Agriculture Organization of the United Nation - FAO. (2011). Codex Committee on fresh fruits and vegetables. Mexico City: Comission del Codex Alimentarius. Retrieved from: http://www. fao.org/fao-who-codexalimentarius/en/

Galán-Soldevilla, H., Pérez-Cacho, P. R., \& Campuzano, J. A. H. (2013). Determination of the characteristics sensory profiles of Aloreña table-olive. Grasas y Aceites, 64(4), 442-452. http://dx.doi. org/10.3989/gya.132312.

Geron, L. J. V., Garcia, J., Costa, F. G., Aguiar, S. C., Oliveira, E. B., Silva, M. I. L., Cabral, L. S., Pierangeli, M. A. P., Zeoula, L. M., \& Mexia, E. E. (2015). Ruminal parameters and nitrogen balance in sheep fed diets containing residue from the extraction of tamarind pulp. Semina: Ciências Agrárias, 36(5), 3411-3420. http://dx.doi. org/10.5433/1679-0359.2015v36n5p3411.

Henrique, M. A., Silvério, H. A., Flauzino, W. P. No., \& Pasquini, D. (2013). Valorization of na agro-industrial waste, mango seed, by the extraction and characterization of its cellulose nanocrystals. Journal of Environmental Management, 121, 202-209. http://dx.doi. org/10.1016/j.jenvman.2013.02.054. PMid:23542530.

Holst, D. O. (1973). Holst filtration apparatus for Van Soest detergent fiber analysis. Journal AOAC, 56, 1352-1356.

Hopkins, D. L. (1996). Assessment of lamb meat colour. Meat Focus International, 5, 400-401.

International Organization for Standardization - ISO. (1988). ISO 8589: sensory analysis: general guidance for the design of test rooms. Geneva: ISO.

International Organization for Standardization - ISO. (1993). ISO 8586-1: sensory analysis methodology: general guidance for the selection and training and monitoring of assessors. Part 1: selected assessors. Geneva: ISO.

Khliji, S., Van de Ven, R., Lamb, T. A., Lanza, M., \& Hopkins, D. L. (2010). Relationship between consumer ranking of lamb colour and objective measures of colour. Meat Science, 85(2), 224-229. http://dx.doi.org/10.1016/j.meatsci.2010.01.002. PMid:20374889.

Leão, A. G., Silva, A. G. So., Moreno, G. M. B., Souza, H. B. A., Perez, H. L., \& Loureiro, C. M. B. (2011). Nutritional characteristics of meat from lambs finished with diets containing sugar cane or corn silage on two levels of concentrate. Revista Brasileira de Zootecnia, 40(5), 1072-1079.
Lima, D. M. Jr., Carvalho, F. F. R., Clementino, R. H., Batista, Â. M. V., Maciel, M. V., Ferreira, J. C. S., \& Pereira, J. D. No. (2014). Performance of sheep fed on annatto byproduct. Italian Journal of Animal Science, 13, 563-567.

Liu, Q., Lanari, M. C., \& Schaefer, D. M. (1995). A review of dietary vitamin $\mathrm{E}$ supplementation for improvement of beef quality. Journal of Animal Science, 73(10), 3131-3140. http://dx.doi. org/10.2527/1995.73103131x. PMid:8617686.

Lousada, J. E. Jr., Neiva, J. N. N., Rodriguez, N. M., Pimentel, J. C. M., \& Lôbo, R. N. B. (2005). Intake and dry matter digestibility of byproducts of fruit processer in sheep. Revista Brasileira de Zootecnia, 34(2), 659-669.

Luciano, G., Monahan, F. J., Vasta, V., Biondi, L., Lanza, M., \& Priolo, A. (2009). Dietary tannins improve lamb meat colour stability. Meat Science, 81(1), 120-125. http://dx.doi.org/10.1016/j.meatsci.2008.07.006. PMid:22063971.

Min, B. R., \& Hart, S. P. (2003). Tannins for suppression of internal parasites. Journal of Animal Science, 81(2), E102-E109.

National Research Council - NRC. (2007). Nutrient requirements of small ruminants (1st ed.). Washington: National Academy Press.

Nguyen, T. H. D., \& Wang, X. C. (2012). Volatile, taste components, and sensory characteristics of commercial brand oyster sauces: comparisons and relation ships. International Journal of Food Properties, 15(3), 518-535. http://dx.doi.org/10.1080/10942912.2010.492542.

Osório, J. C. S., Osório, M. T. M., \& Sanudo, C. (2009). Sensorial characteristics of sheep meat. Revista Brasileira de Zootecnia, 38, 292-300.

Priolo, A., Micol, D., Agabriel, J., Prache, S., \& Dransfield, E. (2002). Effect of grass or concentrate feeding systems on lamb carcass and meat quality. Meat Science, 62(2), 179-185. http://dx.doi.org/10.1016/ S0309-1740(01)00244-3. PMid:22061409.

Resconi, V. C., Campo, M. M., Furnols, M. F., Montossi, F., \& Sañudo, C. (2009). Sensory evaluation of castrated lambs finished on different proportions of pasture and concentrate feeding systems. Meat Science, 83(1), 31-37. http://dx.doi.org/10.1016/j.meatsci.2009.03.004. PMid:20416726.

Rousset-Akrim, S., Young, O. A., \& Berdagué, J. L. (1997). Diet and growth effects in panel assessment of sheep meat odour and flavor. Meat Science, 45(2), 169-181. http://dx.doi.org/10.1016/S03091740(96)00099-X. PMid:22061301.

Santana, N. B. Fo., Oliveira, R. L., Cruz, C. H., Leão, A. G., Ribeiro, O. L., Borja, M. S., Silva, T. M., \& Abreu, C. L. (2016). Physicochemical and sensory characteristics of meat from young nelore bulls fed diferente levels of palm kernel cake. Journal of the Science of Food and Agriculture, 96(10), 3590-3595. http://dx.doi.org/10.1002/ jsfa.7546. PMid:26608628.

Statistical Analysis System - SAS. (2001). General linear model: 9.0. Cary: SAS Institute.

Uchoa-Thomaz, A. M. A., Sousa, E. C., Carioca, J. O. B., Morais, S. M., Lima, A., Martins, C. G., Alexandrino, C. D., Ferreira, P. A. T., Rodrigues, A. L. M., Rodrigues, S. P., Thomaz, J. C. A., Silva, J. N., \& Rodrigues, L. L. (2014). Chemical composition, fatty acid profile and bioactive compounds of guava seeds (Psidium guajava L.). Food Science and Technology, 34(3), 485-492. http://dx.doi. org/10.1590/1678-457x.6339.

Valadares, S. C. Fo., Magalhães, K. A. S. C., \& Rocha, V. R. Jr. (2006). Tabelas brasileiras de composição de alimentos para bovinos (2. ed.). Viçosa: UFV.

Vasta, V., \& Luciano, G. (2011). The effects of dietary consumption of plants secondary compounds on small ruminants' products quality. Small Ruminant Research, 101(1-3), 150-159. http://dx.doi. org/10.1016/j.smallrumres.2011.09.035. 